\title{
Extremismo y desencanto. El nacimiento de la modernidad del espíritu de la política radical
}

\section{Extremism and disenchantment. The birth of modernity from the spirit of radical politics}

\author{
FERNANDO BAYÓN \\ Instituto de Filosofía - CCHS/CSIC
}

\begin{abstract}
RESUMEN. El ensayo consta de tres partes: primera, un breve estudio histórico del surgimiento de las políticas radicales, con especial atención al papel político desempeñado en Europa a lo largo del siglo XVI por las revoluciones sociales inspiradas en el cristianismo reformado. Segunda, una lectura crítica de la secularización como paradigma de modernización que transformó a los dioses movilizadores del radicalismo político. Incluye un comentario del debate entre Karl Löwith y Hans Blumenberg en torno al surgimiento de una concepción moderna de la temporalidad histórica y a la relación entre progreso y escatología. Y una tercera, un apunte filosófico sobre el desplazamiento semántico del término «extremismo» como síntoma del olvido posmoderno de lo político. Finalmente, el análisis histórico de las relaciones entre extremismos y desencantamiento se centra en la importancia que adquiere la ficción como figura del poder político.
\end{abstract}

Palabras clave: secularización, extremismos políticos, religión y revolución, guerras campesinas, Deustche Bauernkrieg, reforma protestante y modernidad, Löwith y Blumenberg, ficción y poder.
ABSTRACT. This essay consists of three parts: first, a brief historical study of the emergence of radical policies, with particular attention to the political role played in Europe throughout the sixteenth century by the social revolutions inspired by Protestant Reformation. Second, a critical reading of secularization as a paradigm of modernization that transformed the former gods, essentials in the political radicalism of the past. It includes a commentary on the debate between Karl Löwith and Hans Blumenberg about the emergence of a modern conception of the historical temporality -and the relationship between progress and eschatology. And third, a philosophical note about the semantic «drift» of the notion of «extremism», as a symptom of the postmodern «oblivion of politics». Finally, the historical analysis of the relationship between Extremism and Disenchantment focuses on the importance that Fiction has acquired in modern times as a figure of political power.

Key words: Secularization, Political Extremism, Religion and Revolution, Deustche Bauernkrieg, Protestant Reformation and Modernity, Karl Löwith and Hans Blumenberg, Fiction and Power. 


\section{Observación preliminar}

El Estado liberal posterior a Locke $(† 1704)$ pudo ser constituido al margen de la morbosa insistencia puritana en el tema de la maldad humana, en adelante relegado por la convicción de signo contrario según la cual una planificación menos coercitiva y disciplinaria del Estado pasaba necesariamente por una fuerte dosis de confianza en la virtud cívica de sus individuos. Occidente olvidó así la dolorosa historia del autocontrol social y sus secretas ideologías religiosas, para consolidar las cuales las revoluciones puritanas del XVII habían hecho que se vieran las caras la disciplina y el activismo políticos: las guerras de las que voy a hacer memoria y cuyo relato me ocupará a continuación fueron guerras de reemplazo de una política de autoexaltación dinástica por otra de signo revolucionario en que el individuo se reivindica frente al súbdito, el partido frente al feudo, la clase frente al estamento y la nación frente al sacro imperio.

Sospecho que cuando hoy las ciencias políticas barajan el concepto de «extremismo» en modo alguno están dispuestas ni a conceder ni a recordar la potencia modernizadora que alguna vez tuvo: el concepto gira una y otra vez alrededor ya de un déficit horroroso de democracia ya de una amenaza no menos terrorífica a la misma, un sabotaje «maximalista» a la politeia soberana con estilos insurgentes, conservadores o restauradores, inspirados de manera innegociable por un mandamiento radical de recuperar algo perdido (fundamentalismo), conquistar algo debido (nacionalismo) o conservar todo lo poseído (totalitarismo); en todo caso, cualesquiera que sean sus objetivos éstos siempre se visibilizan a través de medios programadamente violentos que usan del terror para quebrar la legitimidad del sistema normativo vigente, subrayando de for- ma mítica las agravantes morales derivadas de su perpetuación (como en el caso de las revoluciones), o bien para exasperar abusivamente los controles para su sostenimiento por encima de la voluntad de una ciudadanía libre (como en el caso de las dictaduras). En su acepción blanda se toma por extremista cualquier radicalización de la geometría del espacio político de partidos, por la izquierda o la derecha; de forma un tanto más científica, cualquier denuncia de la ilegitimidad del orden sociopolítico existente y su pobreza de alternativas, cuyo discurso exija recurrir a la violencia de medios extralegales o a una extralimitación de los procedimientos normativos que constituyen el proceso político democrático ${ }^{1}$.

Cada vez que hablamos de extremismos políticos estamos incurriendo en una hermenéutica del espacio de poder establecido. Dicho otro modo, hablar de extremismo político implica participar críticamente de una cierta retórica de la alteridad, por emplear la fórmula del helenista François Hartog 2: toda estructura de poder mínimamente estabilizada funciona como referencia ideal desde la que se construyen y visibilizan esos potenciales políticos de riesgo radical que llamamos extremismo. El mecanismo del poder instituido pretende alcanzar su grado deseado de cohesión normativa mediante un doble expediente de externalización de sus miedos y construcción de eso «totalmente otro», puramente horroroso y negativo, deslocalizado del régimen de lo propio y normal: el peligro es su ontología. Pero la filosofía política, menos aún la más comprometida con los derechos humanos y la democracia, no puede obviar que el auténtico extremismo político radica, más de una vez, no tanto en las posiciones definidas como tales sino exactamente en esa misma maniobra de definirlas y sus consecuencias. Y ésta es la perspectiva que me interesa aquí ${ }^{3}$. El 
ensayo consta de tres partes: primera, un breve estudio histórico del surgimiento de las políticas radicales; segunda, una lectura crítica de la secularización como paradigma de modernización que transformó a los dioses movilizadores del radicalismo político; y una tercera, un apunte filosófico sobre el desplazamiento semántico del término extremismo como fetiche del olvido posmoderno de lo político.

\section{Primera parte: breve genealogía de la política radical}

\section{Comencemos con una Exhortación a la paz para poder hablar de la guerra}

Trasladémonos a $1524 \ldots$ en los alrededores de Nürnberg encontramos el foco desde el que se desató una cadena de levantamientos campesinos contra el régimen feudal de los príncipes alemanes en una época crítica para el Sacro Imperio Romano Germánico. Insurgencias que se expanden por el corazón de la Europa carolina (Würtenberg, Turingia, Franconia, cantones suizos, Sajonia, Alta Suabia...), llegando a casi todos los confines austroalemanes de los Habsburgo. Fue una guerra de artesanos y mineros, de cazadores y madereros; pero también de pequeños burgueses y jueces rurales, que dieron lugar a una fraccionada liga de oprimidos de fuerte impronta cristiana, hecha de anabaptistas antiseñoriales y antifeudales zwinglianos, abolicionistas de la servidumbre reclutados entre las fraternidades evangélicas de aquel continente imperial cuyo rosario de príncipes y margraves se entretenía con sus faidas (guerras privadas).

Ventilada a base de violencias sin caudillos claros, la mal llamada Deutsche Bauernkrieg dio expresión a una serie de movimientos colectivistas que nunca llegó a conquistar las ventajas propias de una Revolución como Dios manda a cambio de padecer los inconvenientes de una caótica organización política muy a propósito para quedar aplastada por los senescales de la Liga Suaba a la que tan agradecidos quedaron Carlos $\mathrm{V}$ y el Papa, pues sus agentes eran bandas incendiarias de miles de hombres que tuvieron en la figura apasionante de Thomas Münzer a su mártir religioso, y en el goethiano guerrero Götz von Berlichingen, «el de la Mano de Hierro», a su caballero franco quizás más romantizado - en competencia con el Florian Geyer que inspirara a Gerhart Hauptmann.

WEISLINGEN [A GOETZ].- Tú miras a los príncipes lo mismo que el lobo a los pastores. Pero ¿es que vas a reprenderles porque velen por el bien de sus vasallos y sus tierras? ¿Están acaso seguros ni un momento frente a esos caballeros fuera de lo regular, que acometen a sus vasallos en todos los caminos y saquean castillos y lugares? [...] ¿no es un buen genio el que a esos príncipes les aconseja pensar en los medios de pacificar Alemania e instaurar un régimen de derecho y justicia, a fin de que todos, grandes y pequeños, puedan gozar, sin sobresaltos, de los beneficios de la paz? [...]

GOETZ.- ¡Ya, ya! ¡Comprendido! ¡Weislingen, si fueran los príncipes según vos los pintáis, no habría más que pedir! ¡Paz y tranquilidad! ¡Ya lo creo! Eso es lo que desean las aves de rapiña para poderse engullir con toda comodidad su presa! ${ }^{4}$

A falta de un programa político unificado, esta Erhebung des gemeinen Mannes [Insurgencia del hombre común], en la que tantos lectores de Engels han querido ver una prefiguración de las revoluciones burguesas de ¡1848!, fijó su acta reformista de agravios en un famoso infolio, Los doce artículos del campesinado de Suabia redactados en Memmingen por Christof Schappelen - pastor zwingliano - y Sebastian Lotzner - curtidor de pieles - , que circuló por aquella Europa superbélica y cismática como un 
fuego literario que ardió en las manos, por ejemplo, de alguien a quien la mística heterodoxa de Münzer siempre exacerbó: Lutero. El artículo tercero del infolio ofrecía una idea del tono insurgente de este cristianismo político:

En tercer lugar, ha sido hasta ahora costumbre para algunos de tratarnos como si fuésemos de su propiedad privada, lo que es de lamentar, considerando que Cristo nos ha liberado y redimido a todos por igual, al siervo y al Señor, sin excepción, por medio del derramamiento de su preciosa sangre. Así, conforme a la Escritura somos y queremos ser libres. Esto no significa que deseamos ser absolutamente libres y no estar sujetos a autoridad alguna.

Ante semejante uso político del nombre de Cristo, Lutero publica en 1525 una advertencia conjunta a la Autoridad y el Campesinado titulada «Exhortación a la paz» de la que el siguiente pasaje es suficientemente expresivo:

Vosotros, Señores, tenéis en contra vuestra la Escritura y la historia, que narran la forma en que han sido castigados los tiranos. También los poetas paganos escriben que es extraño que el tirano fenezca de muerte natural [alusión a las «Sátiras» de Juvenal], y que lo más corriente es que muera estrangulado o de muerte violenta. Puesto que es indudable que regís de manera tiránica y cruel, que prohibís el evangelio, que oprimís y vejáis tan abusivamente a los pobres, el único consuelo, la única esperanza que os resta es el perecer de la misma suerte que vuestros congéneres. Observad cómo todos los reinos han sucumbido por la espada: los asirios, los persas, los griegos, los romanos, y que al fin han sido aniquilados como ellos habían destruido antes a los demás. Con ello está probando Dios que es el juez de la tierra y que ninguna injusticia quedará sin castigo. Por eso, si no os enmendáis, tened la seguridad de que la misma sentencia os alcanzará a vosotros, sea ahora o sea después.

Vosotros, los campesinos, también tenéis en contra la Escritura y la experiencia, que prueban que jamás se ha consumado felizmente ninguna revuelta. Siempre se atuvo
Dios con rigor a estas palabras: «El que desenvaina la espada perecerá por la espada» [Mt 26, 52]. Estad seguros de que también habéis incurrido en la cólera divina, vosotros, que cometéis la injusticia de erigiros en jueces y vengadores propios, y que además portáis indignamente el nombre de cristianos. Aunque logréis la victoria, aunque destruyáis a todos los señores, acabaréis por desgarraros mutuamente como bestias feroces. No es el espíritu, sino la carne y la sangre quien os gobierna; por eso, no tardará Dios en enviaros un espíritu malo que os trate como trató a $\mathrm{Si}$ quem y Abimélek [Jueces 9, 22ss] ${ }^{5}$.

Para el conservador Lutero, padre de la Reforma protestante, Dios es el enemigo tanto de los tiranos como de los revolucionarios. Él quiere hace valer una Escritura por encima de las escrituras de la tiranía y la revolución. Su propedéutica para evitar la devastación del país alemán pasaba por la penitencia, el contrato amistoso entre príncipes y trabajadores, y la aceptación del sufrimiento humano, una medicina sierva de la razón teológica.

Pues aquello que más temía este Lutero falsamente conciliador era la tensión secularizadora que por primera vez se pronunciaba en Europa a través de las guerras de campesinos del siglo XVI, en la medida en que sus fracasados revolucionarios invocaron a Dios para ganarse mejor la Tierra (sus ríos, sus maderas, sus pastos, sus venados), dando así curso a un proyecto de mundanización cuyos efectos políticos habrían de ser apoyados por seres que no eran necesariamente antirreligiosos ni antiautoritarios, sino antes bien espíritus cuyas metafísicas eran radicalmente compatibles con la reestructuración de las cosas de este mundo tanto en el modo como en él se comenzaba a modular la trascendencia cuanto en la forma como en él se deseaba construir el poder.

Creo que es legítimo pensar que fue precisamente la obra de aquellos santos 
que disintieron profundamente de la exhortación a la paz luterana lo que hizo de paradójico disparadero de la Modernidad temprana en su versión política.

\section{Extremismo y modernización: guerras divinas de hombres sin amo}

Michael Walzer dedicó su libro La revolución de los santos ${ }^{6}$ precisamente a estudiar los orígenes sociales de la política radical, tomando como leitmotiv la actividad autodisciplinada de los santos calvinistas, agentes de la destrucción del Antiguo Orden en los albores de la Revolución Inglesa de 1640. Una nueva clase de hombres asomaron a la historia de la primera modernidad política al doblar el siglo de los Bodin (†1596), Maquiavelo $(\uparrow 1527)$ y el apaciguacionista Lutero. Había una nota que los diferenciaba de cualquier experiencia reformadora precedente: estos disciplinarios isabelinos del final de la época Tudor (1558-1603), o aquellos calvinistas ingleses del período Estuardo (1603-1714), desplazaron el énfasis de la acción política desde la figura maquiavélica del Príncipe hasta la figura del santo, el nuevo hombre privado e independiente, el descreído de la cadena del ser, en quien es posible comenzar a rastrear señas de ciudadanía tales como la virtud cívica y la conciencia de que la política era traducible por un trabajo que exigía minuciosa y continua diligencia mundana (rompiendo así con la antigua tradición estoica según la cual la política es de esas cosas que «ni está en nuestras manos ni es de nuestro interés», en palabras del romano Epícteto - que tan convenientes fueran para subvencionar el sometimiento popular durante el régimen feudal-).

$\mathrm{Me}$ interesa el relato fuertemente ideológico de las guerras de estos santos calvinistas como agentes de modernización política en los siglos XVI y XVII. Su fiebre renovadora comenzó destruyen- do la vieja metaforología organicista del estado social conforme a la cual el Rey era el único factor de integración mientras los hombres eran literalmente miembros vicarios sin legitimidad para desafiar ni su autoridad ni su sabiduría ${ }^{7}$. Es cierto, como recuerda Walzer, que el príncipe de Maquiavelo había sido el primero de una serie de «hombres sin amo» de los siglos XVI y XVII: héroes y villanos de su tiempo, que habían cortado sus ataduras orgánicas, jerárquicas y particularistas, exhibiendo a cambio buenas dosis de ambición reformista, cálculo ideológico e irreverencia racional ante los misterios medievales con que se quería aureolar a la política bajo una mística de ritos y magias que echara de ver a ojos del pueblo que los asuntos de la polis les eran metafísicamente inasequibles. (Y no conviene echar en saco roto la herencia estremecedora de esta tradición medieval nunca del todo abolida: el siglo XX se empeñó en creer y hacer creer el célebre aforismo de Hugo von Hofmannsthal contenido en su Libro de los amigos: «La política es magia. Los poderes sólo obedecerán a aquel que sepa conjurarlos»).

Shakespeare, el mejor pensador de lo político en el tránsito del XVI al XVII, acertó a describir en su Enrique $V$ (1599) cómo el trono comenzaba a ser visto por los extremistas de la temprana modernidad como un lugar vacío de Dios, sólo sustentado por la magia del ceremonial que cada vez menos lo convertía en un espacio protegido e inconquistable...

REY ENR. [...] Y, ¿qué poseen los reyes que no posean también los simples particulares, si no es el ceremonial, el perpetuo ceremonial? Y, ¿qué eres tú, ídolo del ceremonial, qué clase de dios eres, que sufres más los dolores mortales de tus adoradores? ¿Dónde están tus rentas? ¿Dónde tus provechos? ¡Oh, ceremonial! ¡Muéstrame lo que vales! ¿Qué tienes que te hace digno de adoración? ¿Hay en ti otra cosa que una situación, una condición, una forma que crean en los otros hom- 
bres el respeto y el temor? Tú aportas menos dicha, puesto que engendras el temor, que no poseen los que temen. ¿Qué bebes con demasiada frecuencia, en lugar de un tierno homenaje, sino la lisonja emponzoñada? ¡Oh, poderosa grandeza, múestrate enferma y ordena luego a tu ceremonial curarte! ¿Piensas que la fiebre abrasadora se irá bajo la influencia de los títulos inflados por la adulación? ¿Cederá el sitio ante las genuflexiones y las profundas reverencias? ¿Podrías, al mismo tiempo que mandas en la rodilla del mendigo, mandar también en su salud? No; sueño soberbio, que juegas tan sutilmente con el reposo de los reyes, soy un rey que te conoce bien y sé que ni el crisma de la unción, ni el cetro, ni el globo, ni la espada, ni la maza, ni la corona imperial, ni el traje de tisú de oro y de perlas, ni la cortesanía atiborrada de títulos que preceden al rey, ni el trono sobre el que se sienta, ni las corrientes de esplendor que bañan las altas orillas de este mundo; yo sé, digo, tres veces pomposo ceremonial, que nada de todo eso, depositado, en el lecho de un rey, puede hacerle dormir tan profundamente como el miserable esclavo que, con el cuerpo lleno y el alma vacía, va a tomar su reposo, satisfecho del pan ganado por su miseria ${ }^{8}$. (Enrique $V$, Act. IV, esc. 1. ${ }^{\mathrm{a}}$ ).

Insensible. Así se le retrató al príncipe de Maquiavelo ante semejantes oscurantismos políticos bajomedievales. Pero al personaje del florentino le faltaba sin embargo un gen de modernidad: la capacidad para integrarse en un sistema social donde la virtud cívica triunfara sobre las lealtades dinásticas, gracias a una metodología política que hiciera de la pasión por rehacer la sociedad la precondición de una teoría del Progreso, como señal de una nueva conciencia activista y liberadora frente a la pasividad medieval (y que además no incurriera en la autoexaltación intrigante y personalista al estilo del Renacimiento italiano, que tan bien describiera Jacob Burckhardt).

Tras la estela de Max Weber, Walzer ${ }^{9}$ rastrea tres fenómenos paralelos relacionados con el surgimiento de la política radical y sus guerras de moderniza- ción. En primer lugar, la ruptura crítica entre la política y la unidad doméstica. Cuando el Estado deja de leerse bajo la metáfora de la familia extendida y el Rey bajo el símil del padre amante, Occidente se pone en el camino de mutar al súbdito orgánicamente obediente por el ciudadano informado y activo. Esto es algo decisivo en los siglos posteriores, particularmente en el XVIII; de hecho, como nos recuerda Roger Chartier en su estudio sobre los orígenes culturales de la Revolución francesa ${ }^{10}$, al término del largo proceso que «inventa» la esfera privada, se instaura la omnipotencia de la cosa pública. Al entrar en la Revolución, el reino pareció sumergirse por completo en la política a base de decretos estatales que no concedían espacio alguno a las pasiones, intimidad, lenguaje, higiene, ambiente de lo individual. Sin embargo, la omnipresencia de lo político, impuesta por la Revolución, no es contradictoria con la «privatización» de las conductas y el pensamiento que la precedieron. «Muy al contrario, la construcción de un espacio de libertad, sustraído al dominio de la autoridad estatal, replegado en lo particular, es precisamente lo que permitió el nacimiento del nuevo espacio público, heredado y transformado a un tiempo por la capacidad creadora de la política revolucionaria» ${ }^{11}$.

En segundo lugar, la aparición de una figura central en la constitución política de los tiempos modernos, el exiliado político. El súbdito que huye, el hombre que se coloca fuera de la ley, intelectuales vagabundos, predicadores dejados en libertad, que reorganizaron tanto sus fervores como sus resentimientos en el deber de crear estructuras de oposición radical al poder establecido, al punto de que Walzer ha podido afirmar que «el radicalismo era la política del exilio, de hombres que no se sentían en casa en la antigua Inglaterra; el calvinismo era la 
ideología de los exiliados, de hombres que habían abandonado padre y patria para enlistarse en el ejército de Cristo. Se trataba, pues, de un ejército capaz de hacer la guerra despiadadamente, porque no sentía nada más que desprecio por el mundo en que se movía» ${ }^{12}$. Y no podemos dejar de hacer memoria del relato poético donde la condición del exilio encuentra una elaboración más monumental y profunda como metáfora teológica de la Caída del hombre: El paraíso perdido (1667/1674), de John Milton. En el libro II, asistimos a un sínodo de ángeles caídos, liderados por Satán, un concilio de «outlaws», que deliberan sobre las modalidades de su venganza contra el orden del Cielo... y habiendo recibido noticias de un lugar de inminente creación, el mundo remoto del hombre, aprueban por unanimidad la propuesta de Belzebú de «arrojar, como fuimos arrojados,/ A sus desamparados moradores; O bien, si no arrojarlos, atraerlos/ A nuestra causa, a fin de que su Dios/ Se convierta en su enemigo, y con mano/ Arrepentida hunda su propia obra». Es probablemente el mejor relato de ese Mal metafísico que estaba dando fuerza inusitada a la imaginación puritana del XVII en todo lo concerniente a la reinvención de los poderes terrenales bajo el signo de la represión: «Ya que, ¿de dónde, sino del autor/ De todo mal puede surgir la malicia/ Tan sutil para a la raza humana/ Malear en su raíz, y Tierra e Infierno/ Mezclar y confundir, todo por odio/ Al supremo Creador?» 13

$\mathrm{Y}$, finalmente, el tercer fenómeno posibilitador de las políticas radicales lo constituyó una nueva metodología pragmática del poder. Los estilos políticamente radicales fueron de la mano de procesos de racionalización, pues toda vez que el poder se visualizó como un objetivo legítimo, el espacio social de su persecución se llenó de examinadores escrupulosos de sus medios y tediosos tácticos de sus fines, de calvinistas exhaustivamente deliberadores y de casuistas jesuíticos que echaron una mano paradójica a su progresivo desencantamiento.

En resumen, la imaginación social de estos santos extremistas y destructores estaba imbuida de la «visión total» de un mundo nuevo, que acaso por vez primera en Occidente desató una imparable crisis de modernización política que, siguiendo a Walzer, podemos definir como el momento en que las antiguas inmunidades quedan súbitamente canceladas y los antiguos patrones de pasividad y acatamiento desbaratados ${ }^{14}$. Resulta impresionante constatar cómo algunos de los procesos de modernización política durante el siglo XVII resultaron en parte de un aggiornamento de las tradiciones teológicamente más excesivas del medioevo, por el cual la idea de Cruzada fue sustituida por la de Revolución.

Al parecer, en la literatura medieval y la casuística renacentista, la guerra era mayoritariamente entendida como una actividad política inherente a la humanidad caída, es cierto; pero los numerosos teóricos de la "guerra justa» ${ }^{15}$ insistían casi siempre en que el combate había de librarse sin celo ni odio, como un acto restringido de resistencia legal, o una violencia homeostática para el mantenimiento de la vida, el orden y la propiedad. A ojos de los magistrados medievales resultaba exótico andar adhiriendo razones a la guerra, ya fueran seculares o religiosas, con el fin de enaltecerla. Era un rito sangriento cuya justicia se hacía depender de su carácter eminente y prolijamente defensivo. Sin embargo, la modernidad comenzó a reconocerse a sí misma cuando los nuevos radicales descubrieron entre la política y la guerra un isomorfismo estructural: la guerra, como la política, había de tener un propósito, perseguir un objetivo, ser pro- 
gramática y razonable. Y resulta terrible constatar cómo el estilo de racionalización de la guerra adoptado por el calvinismo del XVII fue una suerte de traducción sui generis de la vieja retórica de la primera Cruzada, nunca mejor ni más desagradablemente expuesta que en este famoso pasaje recogido por el fundador del Císter, Bernardo de Claraval (1090-1153), en su Elogio de la nueva milicia templaria:

Mas los soldados de Cristo combaten confiados en las batallas del señor, sin temor alguno a pecar por ponerse en peligro de muerte y por matar al enemigo. Para ellos, morir o matar por Cristo no implica criminalidad alguna y reporta una gran gloria. Además, consiguen dos cosas: muriendo sirven a Cristo, y matando, Cristo mismo se les entrega como premio. Él acepta gustosamente como una venganza la muerte del enemigo y más gustosamente aún se da como consuelo al soldado que muere por su causa. Es decir, el soldado de Cristo mata con seguridad de conciencia y muere con mayor seguridad aún.

Si sucumbe, él sale ganador; y si vence, Cristo. Por algo lleva la espada; es el agente de Dios [Rom 13, 4], el ejecutor de su reprobación contra el delincuente [1 Pe, 2, 14]. No peca como homicida, sino - diría yo- como malicida, el que mata al pecador para defender a los buenos. Es considerado como defensor de los cristianos y vengador de Cristo en los malhechores. Y cuando le matan, sabemos que no ha perecido, sino que ha llegado a su meta. La muerte que él causa es un beneficio para Cristo [Flp 1,21]. Y cuando se la infieren a él, lo es para sí mismo. La muerte del pagano es una gloria para el cristiano, pues por ella es glorificado Cristo. En la muerte del cristiano se despliega la liberalidad del Rey, que lleva al soldado a recibir su galardón. Por este motivo se alegrará el justo al ver consumada la venganza. Y podrá decir: Hay premio para el justo, hay un Dios que hace justicia sobre la tierra [Sal 57, 12]. No es que necesariamente debamos matar a los paganos si hay otros medios para detener sus ofensivas y reprimir su violenta opresión sobre los fieles. Pero en las actuales circunstancias es preferible su muerte, para que no pese el cetro de los malvados sobre el lote de los justos, no sea que los justos extiendan su mano a la maldad ${ }^{16}$.

Más allá de los ecos bastante escalofriantes que cualquiera de nosotros podamos registrarles a estas palabras en la actualidad, lo que interesa es mostrar cómo los procesos de racionalización política (es decir, la motivación legal de la praxis política gracias a una constitución pública de razones y fines) no inmunizan a las sociedades ante una posible inflación de las justificaciones para la violencia. Antes al contrario. Tampoco en esto podemos olvidar a Hobbes: «por regla general aquellos que apelan a la razón para decidir cualquier controversia se están refiriendo a la suya propia» ${ }^{17}$. El remake calvinista del matrimonio entre el Cielo y la Tierra a través de la guerra santa, algo que fue diseñado por el cristianismo precismático de Bernardo de Claraval, sirvió ya no para inspirar una cruzada sino para apoyar una «revolution in progress»: pues lo que está en juego ahora ya no es el control sobre los santos lugares (de Jerusalén) sino el autocontrol del hombre moderno en un nuevo mundo de disciplina, vigilancia y trabajo.

Según el historiador Christopher Hill, el gran especialista del siglo XVII, al pensamiento de los radicales habría de sumársele, además, dos líneas entrelazadas. Una es la creencia en la evolución de la verdad y la revelación continua (una creencia a menudo relacionada con el descubrimiento del Nuevo Mundo: «se han encontrado unas nuevas Indias de Tesoros celestiales [...] y todavía pueden existir más»); lo que Milton llamaba el «progreso diario de la luz de la verdad». Es decir, la doctrina del evangelio sempiterno que movía a la más radical liberalidad y tolerancia ante cualquier cosa que oliera a nuevo. Y la otra es la «confianza en el Espíritu Santo dentro de uno»: esto es, en la propia «verdad experimentada» en cuanto opuesta a las verdades tradicio- 
nales transmitidas por otros. Estos dos factores religiosos combinados tuvieron una consecuencia radical: la idea de novedad, de originalidad, de revolución, dejó de ser nefanda para convertirse en deseable ${ }^{18}$.

¿Qué había tras la guerra de los santos? - se pregunta finalmente Walzer-:

Fundamentalmente dos cosas: un feroz antagonismo tanto con el mundo tradicional como con el modelo predominante de relación entre los hombres y una aguda aprensión — quizás no poco realista - respecto de la maldad humana y los peligros del desorden social. Los santos trataron de uncir a toda la humanidad al yugo de una nueva disciplina política, impersonal e ideológica, que no estuviera basada en la lealtad y el afecto, tan poco abierta a la espontaneidad como al caos o al delito. Esta disciplina no dependería de la autoridad de reyes o señores paternales ni de la obediencia de súbditos pueriles y confiados. Los puritanos trataron de hacer de esta disciplina un acto voluntario como el contrato mismo, objeto de un acto individual y colectivo de voluntad. Pero voluntario o no, su nota distintiva fue la represión ${ }^{19}$.

\section{Segunda parte: lectura (muy) crítica de la secularización}

\section{La secularización y sus todavías}

«Un Dios tranquilo tranquiliza todas las cosas» (Calvino, Instituciones, III).

¿Qué sentido tiene preguntar en el siglo XXI por el surgimiento de las políticas radicales en Occidente? Querría adelantar aquí una hipótesis: los avatares históricos de los extremismos políticos han sido en una medida notable el reflejo de los avatares históricos de los dioses que los inspiraron desde el comienzo. Por lo tanto, creo que para poder hablar de la actualidad del radicalismo político desde nuestro imaginario posmoderno hemos de permitir a la secularización que haga su entrada en la discusión, como teorema explicativo del surgimiento del mundo moderno.

Una nota preliminar, sin embargo: hoy resulta francamente improductivo empeñarse en asociar la tesis de la secularización con una supuesta debacle de la religión, o una pérdida total de su importancia en tanto «energía motivante» individual y social, ilusión quizás justificable bajo el imperio de la sociología de finales del XIX y el influjo del positivismo anticlerical de Comte en particular, a cuya luz la secularización se divulgó como un programa de ideología política al servicio del desmontaje de los marcadores religiosos en la sociedad, la escuela o la ciencia $^{20}$. Guste o no, la utilidad de este concepto sociológico finisecular ha quedado exhausta. En nuestro tiempo, la tesis de la secularización ni contiene ni ampara la fulminante pregunta por las condiciones que hicieron posible el olvido de lo religioso sino, de forma más realista, por las de su espacio político de cambio. Por ello, la secularización es una tesis que no permite pensar en la destrucción de lo religioso desde afuera sino en su transformación desde dentro. Como afirma Niklas Luhmann, «la secularización es un concepto que está recortado sobre un mundo observable policontextural, en el cual los contextos de los observadores ya no son idénticos desde el Ser o desde Dios ${ }^{21} \gg$.

No podemos interpretar la secularización en términos de pérdida. Hay que someter a examen filosófico la peligrosa artificiosidad de esas actitudes nostálgicas de un pasado al que atribuyen una integridad canónica supuestamente herida o menoscabada por los procesos secularizadores. Como asegura Hermann Lübbe en su libro Säkularisierung. Geschichte eines ideenpolitischen Begriffs (Secularización. Historia de un concepto de la política de las ideas) ${ }^{22}$, al hablar de secularización no se está haciendo referencia a 
una atrofia de la religión o a una merma ilegítima de lo religioso (el atributo de ilegitimidad formó parte durante el siglo XIX del proprium de la palabra «secularización») sino que más bien se está asumiendo el reto de entrar en relaciones con una serie plural de transformaciones de los fenómenos y experiencias espirituales anteriores, que han dado paso o lugar a esos procesos socio-culturales y políticos que han ayudado a diseñar el horizonte de la última modernidad. Esa idea de la ex-propiación carece hoy por completo de la intensidad que pudo tener en el pasado dentro de ciertos esferas del discurso jurídico, máxime si nos vemos obligados, como ocurre hoy, a pasar de la idea (falsamente original) de secularización en tanto herida practicada con ilegitimidad y violencia por la Modernidad en el cuerpo de las instituciones religiosas de antaño, a otra visión mucho más actual, pertinente y compleja, en la cual es la misma Modernidad secularizadora quien parece herida de muerte por su propia historia así como por las recurrentes violencias y paradójicos éxitos de sus programas de autolegitimación.

La revocación del «divorcio» entre Cielo y Tierra ${ }^{23}$ marcó el devenir de la Modernidad europea. Un progresivo crecimiento de la autoconfianza del hombre en sus propias fuerzas predictivas, en sus estrategias de control científico del entorno, ayudaron a que los poderes trascendentes del cielo fueran reabsorbidos por y para el mundo, que se hizo depositario de poderes que neutralizaron poco a poco aquel absolutismo teológico —en palabras de Hans Blumenberg - cuyos designios habían abocado a la humanidad medieval a una situación constante de exposición a poderes ocultos, veleidosos, obedientes a una voluntad Arbitraria e Inescrutable ${ }^{24}$.

La secularización atiende normalmente por una variedad bien popularizada de nombres [«racionalización», «desmagificación», «desencantamiento», «mundanización», «desdivinización»] siendo realmente una hipótesis, y como tal muy discutible, acerca del surgimiento de la modernidad, que insiste en que los principales hitos de ésta (Historia Universal, Progreso, etc.) son traducciones de los principales constructos teológicos de la escatología cristiana al lenguaje mundano. Con lo cual los partidarios de la secularización hablan de la Modernidad al mismo tiempo que saludan una deuda de Occidente con el judeocristianismo que aún sería nuestro deber amortizar. No me extenderé mucho sobre este tema, pues tan sólo pretendo extraer de aquí una brevísima lectura política de la secularización. En todo caso, es preciso poner en el centro del discurso siquiera sean las líneas generales de la ya clásica disputa entre Hans Blumenberg y Karl Löwith.

La tesis principal de Löwith en su célebre Weltgeschichte und Heilsgeschehen (Historial universal y acontecimiento salvífico) ${ }^{25}$, a saber, que la autoconciencia histórica de Occidente es escatológica y que la secularización es su «unidad cultural específica», se ramifica en otras no menos ambiciosas. De aquí se deduce que la moderna Geschichtsphilosophie (filosofía de la historia) centrada en la idea global y universalista del progreso (Fortschritt) es el resultado de una secularización de la «teología de la historia» de orientación judeocristiana. Es decir, el efecto de la sustitución de la Providencia por el Progreso y de Dios por el hombre como sujeto absoluto de la historia. En un marco de pensamiento que asume la pérdida de operatividad de la estructura «cielo/tierra» o «más allá/mundo» el progreso vendría a ocupar un lugar funcionalmente similar al que ocupaba Dios en el pensamiento judeocristiano en tanto proveedor supranatural de destinos, del que el progreso sería ahora su versión in- 
manentizada, la versión de un tiempo que tiene historia.

Es cierto que Löwith no pregona, ni mucho menos, el retorno a la tradición contra la modernidad: la «vuelta a las fuentes» supondría aceptar la tesis de la secularización como amenaza o falsificación, como profanación de una pureza originaria, de un núcleo sustancial y auténtico de la escatología antes del evento trágico de su mundanización. Una nota: el esquema de la mundanización como amenaza no puede por menos de resultarle ajeno al cristianismo en tanto religión cuyo cuerpo dogmático se articula «desde el principio» en torno a una kénosis o vaciamiento terrenal de Dios en un sí mismo que muere bajo la persona consustancial del hijo. Löwith es hipersensible a la secularización en tanto experiencia específica del tiempo marcada por esa ideología futuro-céntrica según la cual el tiempo corre irreversible y acumulativamente hacia una meta futura. Esta convicción del Occidente moderno, tanto en sus rasgos fundamentales como en sus desarrollos, tanto en su génesis como en su historia, es para él incomprensible sin la referencia a la matriz judeocristiana de la modernidad. Que el fenómeno de la supravaloración moderna de la Historia como temporalidad futurocéntrica hunde sus raíces en la escatología judeocristiana (haciendo que el ilustrado comprenda el telos como eschaton, el final como senti$d o$ ), éste es el aspecto discutible no ya de la tesis de Löwith sino más bien de la propia secularización como hipótesis válida del surgimiento del mundo moderno ${ }^{26}$.

El mundo poscristiano se presenta bajo una doble luz: por su origen cristiano, se dirige escatológicamente hacia un cumplimiento del sentido; pero los medios que conducirían a este fin están totalmente secularizados. Con otras palabras, se produce, sí, una secularización de los medios; pero dentro de una matriz escatológica donde cierto dejo de la teología de la historia sigue haciendo de las suyas en los discursos más ilustrados. Por tanto, para Löwith, la historia de Occidente es hasta cierto punto cristiana $y$ no cristiana: pues traslada al mundo unas expectativas originariamente mesiánicas o escatológicas - sea en forma de progreso, de revolución mundial o de utopía política-; para constatar a renglón seguido que el cristianismo ha mostrado una bien probada incapacidad para impregnar el mundo como tal mundo.

Precisamente aquí la figura de Hans Blumenberg impone su avasallador talento histórico-crítico. Hay que tener en cuenta qué es lo que pretende desconstruir este paisano de Thomas Mann cuando se afirma, como se suele hacer, que pretende destruir la categoría de secularización. Pues no se trata del concepto de partida que podamos tener de la misma en tanto «desaparición de vínculos religiosos, de planteamientos trascendentales, de expectativas de una vida en el más allá, de actos de culto y de convenciones rituales tanto en la vida privada como en la público-cotidiana» ${ }^{27}$. Todo eso Blumenberg lo contempla sin pathos ninguno. Igual que la consabida separación histórica entre Iglesia y Estado, el debilitamiento de la atadura entre la política y la religión, así como la emancipación del arte, la ciencia, la jurisdicción y la filosofía de las esferas de la fe y sus im-posiciones eclesiásticas.

La secularización a la que se refiere el genio severo de Blumenberg como «categoría de la sinrazón o injusticia histórica» es algo distinto y más profundo: pues apunta a algo más que una mera disminución cuantitativa de rasgos religiosos y eclesiásticos. Con una astucia extraordinaria, Blumenberg detecta en las interpretaciones positivas de la secularización a cargo de tantos «teólogos de la 
crisis» el patrón bien conocido de todos los intentos de autoconservación de instituciones amenazadas en su existencia. La revalorización de la secularización empieza a convertirse en tarea urgente del propio cristianismo a partir del momento en que éste no acaba de lograr del todo la autodefensa dogmático/teológica y la resistencia institucional/eclesiástica frente al imparable mundo moderno. Es un combate en retirada que consigue aminorar las discrepancias entre el cristianismo y el mundo moderno sin detener la creciente crisis de plausibilidad de los contenidos tradicionales de la fe. La secularización ofrece al cristianismo la insi/diosa salvación que se suele hallar en los males menores: puesto que ya no marcamos el paso — se dice a sí misma la teología judeocristiana-, aceptemos y apoyemos la idea que al menos adhiere al imaginario europeo la convicción de que el camino entero es una huella nuestra apenas modificada.

Sobre todo en su imponente Die Legitimität der Neuzeit ${ }^{28}$, la autoridad de Blumenberg sobresale al rechazar que la expectativa histórico-filosófica de un Final y la moderna idea de Progreso sean metamorfosis de la escatología neotestamentaria: hay una razón sencilla que lo avala, tan sencilla como el hecho de que la escatología neotestamentaria es «intraducible» a un concepto de Historia, sea de la índole que sea. La moderna filosofía de la historia no es por lo tanto una deformación de la soteriología, sino que todo lo más constituye su relevo ${ }^{29}$. Y se equivocan los que defienden que la escatología historizada, esa pasión finalística, esa frenética futurolatría de nuestras modernidades políticas, esconde bajos sus aceleraciones una sustancia teológica. Así, la moderna idea de «progreso», dirá Blumenberg, no es un «secularizado» de la expectativa escatológica de una consumación futura: antes al contrario es la fuerza motriz de la moderna voluntad de autoafirmación, surgida con la emancipación racional del absolutismo teológico y sus divinas arbitrariedades. En resumen, muchos conceptos y fenómenos modernos (subjetividad absoluta, historia y nación) por su propia sustancia no tienen que ver con los acontecimientos teológicos de la Edad Media, pero se han hecho quizá cargo de su función: una cosa es que vengan a desempeñar un papel en alguna medida equiparable y otra muy distinta que tengan la misma sustancia que los conceptos y prácticas reemplazados, que sólo gracias a una actitud insincera o poco legítima pueden seguir arrogándose la calidad de matrices sagradas.

Quien trata de secularización trata de las metamorfosis de lo divino. Quien trata de la secularización pierde el derecho a quejarse de que lo divino esté todavía «siempre detrás». Esto deberían tenerlo en cuenta a mi parecer los filósofos y sociólogos de lo político que acostumbran a invocar a la secularización como un antídoto contra el extremismo de ciertos fundamentalismos religiosos (con peligrosa facilidad: islámicos): hasta el punto de que hay ocasiones en que parecería que a ojos de muchos analistas la causa de la persistencia de estos extremismos de signo religioso habría que ir a buscarla en una saecularizatio interrupta; la solución no pasaría por la muerte de Dios, sino por la experiencia de un Dios urbanizado que pusiera en obra el dictado de - quién lo diría- Calvino: «un dios tranquilo, tranquiliza todas las cosas».

Creo, en cambio, que hablar de secularización incompleta es, probablemente, una contradicción. Y que, por extraño que parezca, determinadas ideologías extremas pueden estar en relación no tanto con las lloradas derrotas de la secularización cuanto con sus unívocas y exageradas victorias. Esto requiere, me temo, una explicación: no estoy defendiendo de 
ningún modo — como algún seguidor en exceso tardío de Dostoievski- que la desdivinización haya supuesto una condición favorable a la violencia [pues si tras la muerte de Dios todo es posible... con Dios en vida lo tuvo que ser forzosamente mucho más], sino tan sólo que la Modernidad, a la hora de legitimarse, bebió de muchas más fuentes que de la mera metamorfosis de los constructos teológicos. No podemos pasar por alto que la secularización es precisamente una hipótesis acerca del surgimiento del mundo moderno que pretende hacer valer el ascendiente de ciertas construcciones de lo divino sobre el relato de los procesos modernizadores, en los que se testa simultáneamente su influencia y su trasformación.

Cuando hablo de una victoria exagerada y unívoca de la secularización me refiero por lo tanto a que su elevación incontestable como teorema explicativo del surgimiento de la Modernidad puede dañar colateralmente la visión de aquellos otros procesos históricos igualmente constitutivos de la misma. Aquel que se lamente porque la secularización, bajo su elogio de la racionalización, deja «todavía» a la religión como un fantasma bastante insidioso, todo lo pálido, desmagificado y mundanizado que se quiera, pero «todavía» lo suficientemente relevante para legitimar un vínculo entre Modernidad y Cristiandad, entre razón y escatología, aquél ha de abandonar esta hipótesis, o enriquecerla, y leer por ejemplo a Blumenberg. Porque la secularización es ese «todavía pos-teo-lógico» que no puede sacudirse la historia de encima sin poner en riesgo su supuesta consistencia explicativa: su única fuerza está en permanecer radicalmente incompleta, si entendemos por incompleta que no está dispuesta a abandonar el judeocristianismo como marca en la ausencia, como huella en el cambio, como espacio fantasmático del discurso, como gen en la descendencia, a partir de la hipótesis de Löwith que hemos comentado ${ }^{30}$.

Dicho plásticamente: quien pide más secularización está pidiendo no más falta de dios sino más dios como falta. No más mundanización sino más dios mundanizado. No más padres muertos sino más escatología como auténtico padre muerto. No por nada gana adeptos entre los filósofos posmodernamente cristianos ${ }^{31}$, esos que abogan con una parte de su cerebro por el debilitamiento radical de cualquier sanción metafísica para el mundo actual y con la otra conceden que Europa no puede ser entendida en absoluto al margen de las hazañas dogmáticas de los partidarios de Cristo.

Como lo que me ocupa es la historia del cambio en las políticas radicales desde su memoria religiosa inicial hasta sus deflacciones contemporáneas, me resulta muy ilustrativo el rótulo bajo el que Marcel Gauchet resume cuál fue el sentido que cobraron las transformaciones de las figuras de lo divino en lo que respecta a las dimensiones inherentes a las relaciones de poder. Gauchet, en su obra El desencantamiento del mundo, habla precisamente del Estado como de un «transformador sacro» ${ }^{32}$.

El nacimiento del Estado es el acontecimiento que parte la historia en dos y hace entrar a las sociedades humanas en una época enteramente nueva: las hace entrar precisamente en la historia, si por esto entendemos no que las hace pasar de la inmovilidad al movimiento, sino que modifica de parte a parte su relación de hecho con el cambio y, consecuentemente, su ritmo real de cambio. Al principio no hay nada de fundamentalmente transformado: se permanece en una economía religiosa de la deuda, de la intangibilidad de las cosas establecidas y, por tanto, en una disposición teórica contra la historia. Pero sea lo que sea de las actitudes y de las creencias de los agentes, de lo que piensen hacer y deseen, están destinados desde ahora, en la práctica, en virtud de la articulación misma de la rela- 
ción social, a cuestionar lo bien fundado de la organización colectiva hasta su fundamento sagrado ${ }^{33}$.

Con la aparición del Estado, lo Otro religioso se reabsorbe en la esfera humana. Y la vieja línea de demarcación, la antigua fractura religiosa que separaba a los hombres de sus Orígenes, impidiendo a la postre que proliferaran divisiones fundamentales en el interior de la humanidad (pues sin excepción estaba integrada por criaturas mortales de un solo Dios), esa línea fronteriza se arroja al siglo, se mundaniza. Con el surgimiento de un aparato de dominación tan colosal como el Estado moderno, dicha demarcación ya no ayuda a separar un «mundo' (másacá) de un «Cielo' (más-allá) mediante un expediente de igualación de todos los hombres en una misma Naturaleza devaluada, sino a separar entre dominadores y dominados en este mundo, «la refracción de la alteridad divina en el interior del espacio social, la concreción de lo extra-humano en la economía del vínculo inter-humano», en palabras de Gauchet, tuvo como consecuencia una multiplicación de las rupturas y las guerras dentro de la humanidad.

Inicialmente, la división, y su retórica, era clara: están los que hablan y ordenan en nombre de los dioses y los que no; los que tienen el control de los ritos en que renace el sentido original de las cosas, y los que no; aquellos en cuya carne se toca literalmente el principio superior que ordena el mundo y aquellos en que desde luego no. Pero algo ocurrió en el devenir de ese transformador de sacralidad que fue el Estado moderno que hizo que las divisiones se acentuaran hasta el extremo: «a través de esta presencia coercitiva, de esta implicación con forma de poder en el seno de los asuntos humanos, los mismo dioses, cogidos como están en los avatares del dispositivo que teóricamente ellos inspiran o determinan, son de alguna manera puestos al alcance y convertidos, en la práctica, en socialmente discutibles» ${ }^{34}$. Merece la pena que recojamos la tesis de Gauchet a este respecto, que resumidamente dice así: «el dispositivo social articulado por la división política parece que no puede funcionar sin remover oscuramente, o poner en cuestión, los fundamentos inmutables y sagrados que supuestamente le dictan su ley. El poder de unos cuantos en nombre de los dioses fue el comienzo, tímido pero irreversible, del poder de todos sobre los decretos de los dioses».

La modernidad política comienza, según creo, a partir de aquí. A partir de la irreversibilidad de ese proceso por el que el poder de la comunidad de hombres nuevos quiere vencer, como hemos visto, sobre el decreto de los dioses así como sobre su monopolio a cargo de una casta de elegidos. Si la anatomía del Estado primitivo estaba preparada para transparentar en este mundo la silueta de Dios y amortiguar cualquier división con el cuerpo colosal de Leviatán, tachonado de individuos-heliánticos cuya salvación pasaba por pactar políticamente sus vidas desde metáforas organicistas, la propia deriva de ese cuerpo-Estado acabó por incluir la promesa de revolucionar inconteniblemente su figura.

\section{Tercera parte: las ficciones extremistas de nuestro extremismo}

Ay, si cada uno es padre y creador de sí mismo, ¿por qué no puede ser también su propio ángel exterminador?

JEAN PAUL, Discurso de Cristo muerto, el cual, desde lo alto del edificio del mundo, proclama que Dios no existe.

\section{Las cínicas tranquilidades de la despolitización}

Sin que resulte contradictorio con lo anterior, la filosofía política desde el si- 
glo XIX liberal hasta nuestros días, con mejor o peor gana, ha tenido que salir al paso de una hipótesis muy extendida que tiende a asociar «modernización» y «despolitización». El lector se la encontrará, con estilos bien diferenciados, en una horquilla de autores que va de Carl Schmitt a Hannah Arendt. Dicho de una forma sucinta y por lo tanto insuficiente: el dato constitutivo de lo político, a saber, la relación conflictiva del hombre con el hombre, ha querido ser borrado a través de plurales semánticas de la neutralización. Entre ellas, la sociedad, la economía y la técnica se han constituido en otros tantos ámbitos lingüísticos de la Modernidad, en centros multifuncionales de neutralización de los conflictos políticos que eran así pastoreados hacia otros niveles donde cobraban un sentido y un destino muy diverso.

Como se recordará, el historiador napolitano de las doctrinas políticas Roberto Esposito, en su libro Categorías de lo impolítico, ha sido uno de los pensadores que con más insistencia han notado cómo la despolitización moderna tiene sin embargo una matriz hobbesiana, es decir, que, por paradójico que pueda parecer a primera vista, la despolitización nació en la cáscara de la «política absoluta» y la obligación soberana. Como vimos, con Hobbes se echó de ver que todo ordenamiento normativo tiene un origen anormal, artificial, no-natural, como un cyborg barroco de excepción, decisional, teratológico podría incluso decirse: «la neutralización del conflicto político siempre puede interpretarse también como neutralización política del conflicto: política de la neutralización» ${ }^{35}$. Cuánto miedo no le daría a la humanidad moderna la política, es decir, la yema del conflicto tú a tú (para el cual Hobbes reservaba la semántica de la guerra civil), para que prefiriera delegar su autoría en la actoría de un monstruo artificial cuyo poder disuasorio radicaba precisamente en el terror que infundía.
Escapar del miedo a traves del terror, ésa es la receta hobbesiana que la modernidad, y sus retóricas, acabaron convirtiendo en la campeona de todas las ideas supervivientes bajo los cambios de la secularización. La idea que deberíamos extraer de aquí es que el siglo XXI (a base de extremismos tan de actualidad como la obsesión securitaria y «auto-conservacionista» del nuevo Bios mundial; las alienaciones hedonistas del turbocapitalismo de mercado; o la sustitución de intereses públicos por intereses privados esgrimiendo de forma mendaz la Razón de Estado en democracias que ya no están a la altura de sus principios de legitimidad ni legalidad), se está construyendo a sí misma en forma de absurdo memorial a Hobbes en igual medida que ha sabido arrancarse la divisa de los puritanos radicales coetáneos suyos. Pues Hobbes, como viera Foucault $-\mathrm{y}$ nos recuerda Yves Charles Zarka - fue alguien muy distinto de ese pensador de la guerra por el que comúnmente se le toma; para Foucault, Hobbes es el pensador de la paz por excelencia o, mejor dicho, un pensador «para el que la guerra se puede detener, para el que la tarea del poder político es precisamente poner fin al estado de guerra» (el bellum omnium contra omnes de Hobbes era una guerra de filósofo que no tenía lugar entre particulares sino entre Estados interpretados como magni homines, y que no tenía salida a no ser por un acto jurídico, la «convención social», que hacía de fundamento del dominio político) ${ }^{36}$. Por su parte, los santos destructores calvinistas hicieron del activismo político el nuevo poder terrenal con que sustituir a conciencia toda forma de usurpación o domesticación de nuestra responsabilidad en este mundo.

En ambos casos, la política pro-activa triunfa sobre las señales de desvío y desistimiento enviadas desde el statu quo. Los radicales de la modernidad tem- 
prana coadyuvaron a que la política venciera sobre las tragedias del Destino, como podría constatar Goethe tras los tiempos de Napoleón, durante sus conversaciones con Eckermann. Y eso es lo que parece que se ha perdido. Los filósofos contemporáneos en Occidente convienen en que la escena políticamente más radical en la posmodernidad sería la del regreso de la propia política a la escena. Y si como Walzer señaló, «en los siglos XVI y XVII era inconcebible una innovación radical en la política (especialmente cuando implicaba la cooperación de muchos hombres) sin el apoyo moral de la religión, y esa religión era lo que proporcionaba el incentivo más importante para la innovación» ${ }^{37}$, ¿qué incentivos podríamos encontrarle hoy a la innovación política en Occidente cuando sus coartadas de trascendencia son como mitos secos sometidos a mil cirugías (algunas, estéticas); las soberanías nacionales son como criadas mudas que pierden el paso tras los daimones de la economía global y la famosa desterritorialización de las lealtades identitarias; mientras que la justicia es un no-lugar en el mundo de la biotecnología, el terrorismo ubícuo y las (auto)inmunizadas doctrinas imperiales estilo Shock and awe (conmoción y pavor) al servicio de la Rapid Dominan$\mathrm{ce}^{38}$ ?

Son muchos los pensadores de (más o menos) nueva hornada que nos hablan con voz alertada de los riesgos de acomodarse a una sensibilidad hiperpolitica, por emplear libremente un subtítulo de Sloterdijk ${ }^{39}$. Pues bien, una lectura política de la secularización nos obliga a cuestionar cuáles han sido los procesos que mediatizaron la historia del Occidente sanamente capitalista y liberal con el resultado de que la categoría tradicional del sujeto políticamente pro-activo diera paso a la categoría pospolítica bien del cínico que contemporiza siempre con la estructura de poder y siempre con un universal «a pesar de que sé que...» en los labios, bien de la víctima que blinda ideológicamente su identidad en tanto efecto de la opresión, naturalizándola, de modo que eleva a la segunda potencia los efectos y la lógica del poder al no atreverse a seguir, por un quietismo a veces comprensible, la consigna sobre la libertad del viejo Sartre: «No se trata de lo que han hecho con nosotros sino de lo que nosotros hacemos de lo que han hecho con nosotros»» ${ }^{40}$.

Lo que separa la febril disciplina política de lo nuevos hombres y sus dioses tiranos en la modernidad temprana de la displicencia in-política de la ciudadanía actual harta de modernidades, quizás sea una consecuencia tardía del triunfo de las posiciones burguesas durante la Ilustración, verdadero hito de los procesos secularizadores. Es decir, ¿podemos identificarnos entre los descendientes del relevo del santo calvinista por el burgués ilustrado, que salta al campo de la Revolución con el equipo de la Crítica en lugar del equipo de la Fe?

En su importante Crítica y Crisis, Reinhart Koselleck expuso cómo a lo largo del XVIII el estrato social burgués se convirtió en un "grupo de hombres que ocuparon las posiciones intelectuales de una nueva sociedad en calidad de representantes y educadores de ésta, al tiempo que negaban el Estado absolutista y la Iglesia imperante a la sazón». La Crítica arrumbó los decisionismos políticos de la fe y puso en marcha un proceso apolítico del «pro»y el «contra». Quizás no nos atrevemos aún a reconocer la deuda que los nuevos tiempos modernos contrajeron con la separación radicalmente ilustrada, primero, entre derecho del poder y derecho de la moral, y segundo, entre sociedad y Estado: los prevolucionarios franceses (como el fisiócrata Turgot — $† 1781-$ ) ahondaron en la escisión entre moral y po- 
lítica al ver que no era el monarca quien debía imperar, sino la justicia en él y a través de él. «Con esta interpretación moral de las tareas políticas del rey, el poder soberano se ve privado de su libertad política de decisión, esto es, de su soberanía absoluta». La Ilustración consiguió que el derecho quedara fijado de modo puramente moral fuera de la esfera de la política, del mismo modo que la sociedad se las apañó para diferenciarse del Estado.

La invocación a la conciencia humana, la postulada subordinación de la política a la moral, invierte los fundamentos del Estado absolutista, pero - y aquí radica el secreto de la polarización de un derecho moral y de un derecho del poder - sin poner aparentemente en tela de juicio la estructura externa del poder propia del Estado. Sólo «las leyes» deben imperar. La normatividad moral constituye la armazón política invisible por la que la sociedad ha trepado como por una rama de hiedra. [...] El secreto político de la Ilustración consistía en que todos sus conceptos - de modo análogo a la toma indirecta del poder [es decir, la utopía] - eran apolíticos de modo invisible. En el anonimato político de la razón, de la moral, de la naturaleza, etc., radicaban su singularidad y eficiencia carácterísticas. Su valor político consiste, precisamente, en ser apolíticas ${ }^{41}$.

Para Koselleck, el anonimato de los grandes conceptos dieciochescos pedía un cumplimiento en la soberanía de la utopía, pero ésta «se transformó en las manos del hombre de los nuevos tiempos en un capital carente de cobertura política ${ }^{42} \gg$. A partir de ahí, la tarea de la humanidad postrevolucionaria de los siglos posteriores consistiría quizá en dar el siguiente paso, aniquilar la utopía como relación indirecta con la política pues ésta exige una coordinación de nuestras posiciones como sujetos históricos imposible de lograr una vez que todos no hemos convencido definitivamente de que la Historia es presa de una dinámica que se escapa a nuestra representación ${ }^{43}$.
El extremismo, en Occidente, ha pasado de la esfera de las (elevadas) acciones a la de las (bajas) pasiones. Ya sea bajo la hipóstasis del cínico, ya bajo la hipóstasis de la víctima, la ciudadanía en el Mundo Moderno puede seguir celebrando todo lo que éste tiene de alienación radical, en la conocida expresión de Hannah Arendt ${ }^{44}$. Estas cínicas parsimonias de la despolitización, - el triunfo planetario de la convicción, puramente ideológica, de que (ya) no hay ni decisiones ni problemas políticos, pues el lugar de las primeras lo ocupan sistemas expertos guiados por criterios de sostenibilidad administrativa, mientras los segundos son casi siempre traducidos a la bizantina terminología de los conflictos culturales-, son el mejor caldo de cultivo de un sinfín de fantasías sobre el extremismo. Eso sin entrar en los dominios disciplinarios del biopoder cuya ontología, como recordaba antes, es el peligro puro. Y su erótica, la amenaza.

\section{Un final extremo: concitando el terror}

«Sin duda que el poder está ligado a unas instituciones, a unos mecanismos, a unas leyes, pero también es un órgano de producción de ficciones», dice Yves Charles Zarka ${ }^{45}$. Hasta cuatro son los registros en que se pueden calificar las figuras políticas de la ficción, según este especialista en Hobbes. El más corriente y clásico, concierne a la política de gobierno como arte de la simulación y el disimulo: la ficción no es cosa de buena o mala voluntad política sino una preestructura del funcionamiento del poder, como detectara, maquiavélicamente, $\mathrm{Ma}$ quiavelo. La segunda figura política de la ficción es institucional, pues no tiene que ver con el engaño como la anterior sino con la dimensión simbólica del poder: el ejemplo más recurrente es el que estudió Ernst Kantorowicz en torno a la doctrina 
del doble cuerpo del rey, el terrenal y el sobrenatural, una ficción que sirvió para forjar el edificio institucional de la monarquía y permitió pensar su continuidad e incluso su legitimidad. El tercer registro de las figuras políticas de la ficción concierne a la filosofía. Al saber, en tanto «ámbito de despliegue de la verdad sobre lo político». Se trata de un registro discursivo que pretende alcanzar la naturaleza de las cosas, del hombre y la sociedad. Este registro es ciertamente importante (aunque la afirmación venga de parte interesada). Y lo es en la medida en que ayuda a desmontar un mito al que Michel Foucault ha dedicado algunas de sus conferencias más citadas:

Occidente será dominado por el gran mito de que la verdad nunca pertenece al poder político, de que el poder político es ciego, de que el verdadero saber es el que se posee cuando se está en contacto con los dioses o cuando recordamos las cosas, cuando miramos hacia el gran sol eterno o abrimos los ojos para observar lo que ha pasado. (...) Hay que acabar con este gran mito. Un mito que Nietzsche comenzó a demoler al mostrar (...) que por detrás de todo saber o conocimiento lo que está en juego es una lucha de poder. El poder político no está ausente del saber, por el contrario, está tramado con éste ${ }^{46}$.

Que el saber es uno de los registros de las figuras políticas de la ficción tiene consecuencias de calado para nuestro tema: si el mito occidental basado en la disonancia saber/poder y la orden metafísica de alejamiento de la política respecto de la Verdad tuvo sus peligros, se puede incluso hacer la tentativa de definir el extremismo por los peligros aún mayores que acarrea el mito contrario, es decir, el empleo del poder político como gran Fortuna o Nemosine que nos pone en contacto con el sol de la Verdad.

Por otra parte, que el olvido, «y aun el error histórico», une y cae dentro de la sintomatología de cualquier cohesión nacional es bien sabido, al menos desde el discurso de Ernst Renan de 1882. Que el olvido obedece en ocasiones a la táctica contenida en aquella frase que, según Ernst Jünger ${ }^{47}$, le gustaba citar a Carl Schmitt, Nom possum scribere contra eum, qui potest proscribere, también. Los poderes seculares producen ficciones que alimentan el interés de ciertos olvidos, y son a la vez la dieta política de ciertas memorias. El nudo gordiano que ata extremismos políticos con desencantamientos religiosos está fabricado de ficciones del poder, hoy como siempre. Quería acabar (este ensayo) con Jünger, pues sus diarios de la guerra incluyen algunas de las declaraciones más obscenamente atractivas sobre el terror como una pura ficción política. El día 23 de mayo de 1945, enterado de la detención de Himmler, el Reichsführer de las SS, mientras iba disfrazado de vagabundo tuerto (haciendo un Wotan ridículo), Jünger observa cuán raro era que su figura apestara a burgués:

Uno pensaría que alguien que organiza la muerte de muchos millares de personas tendría que diferenciarse visiblemente de todos los demás hombres y que a su alrededor habría un resplandor terrible, un brillo luciferino. En vez de tales cosas, esos rostros, que uno encuentra en toda gran ciudad cuando anda buscando una habitación amueblada y nos abre la puerta un funcionario que se ha jubilado anticipadamente.

En eso se hace patente, por otro lado, hasta qué grado ha penetrado el mal en nuestras instituciones: el progreso de la abstracción. Detrás de la primera ventanilla puede aparecer nuestro verdugo. Hoy nos manda una carta certificada y mañana, la sentencia de muerte. Hoy nos hace un agujero en el billete de tren, y mañana, un agujero en la nuca. Y ejecuta ambas cosas con la misma pedantería, con el mismo sentido del deber. Quien no ve eso ya en los andenes de las estaciones y en el keep smiling de las vendedoras camina por nuestro mundo como un daltónico. Ese mundo no tiene sólo zonas y períodos terribles, sino que es terrible de arriba abajo. [...] El 
pensamiento de que millones de personas dejan este mundo porque un señor, un tal Himmler, acciona la palanca de la máquina de la aniquilación, ese pensamiento forma parte de las ilusiones ópticas. Si ha estado cayendo la nieve todo el invierno basta la pata de una liebre para que se precipite al valle el alud. No conocemos el otro lado. En el instante en que la víctima cruza el portal de la gloria olvida a su verdugo; éste queda atrás, como uno de los fantasmas del mundo del terror, como un portero vestido con la librea del tiempo ${ }^{48}$.

El terror millonario se disfraza de burgués y luego quiere escabullirse como un mendigo, el asesinato vistiendo las galas de un corriente hijo del siglo, igual que el olvido trasviste la violencia con el género que se quiera: fortaleza cívica o unión y coraje nacional, por ejemplo. Hay que pensar desde este impropio no- sotros que esgrimimos cada vez que hablamos de los ataques del extremismo de los otros, la posibilidad siguiente: puede, sí, que ciertos extremismos políticos tengan mucho de ilusiones ópticas de un Occidente liberal que se complace en organizarse socialmente disciplinando a sus buenos consumidores con un excelso catálogo de miedos, sin querer saber nada sin embargo de los ultrajes que implica su inmoderada exhibición. Nuestros relatos, figuras políticas de esa ficción que llamamos Occidente, no deben despreciar a los dioses extraños bajo la fácil especie del extremismo sino reconocerles un marco de narración y poder en que se secularice el fundamento de sus violencias y se apalabre la violencia hasta sus fundamentos.
1 Vid., el estudio de Lipset, Seymour Martin; Raab, Earl, La política de la sinrazón. El extremismo de derecha en los Estados Unidos, 1790-1977, México DF, FCE, 1981, p. 20. [The Politics of Unreason. Right-Wingt extremism in America, 1790-1970, New York, Harper \& Row, 1970].

2 Hartog, François, El espejo de Herodoto, México, FCE, 2003, pp. 207ss.

3 Vid., sobre la relación entre «extremismo», «radicalismo» y «revolución»: Hobsbawm, Eric J., Revolucionarios. Ensayos contemporáneos, Barcelona, Ariel, 1978, pp. 294ss.

4 Goethe, Johann W., Goetz von Berlichingen (Acto I, Escena III), en Obras Completas, Tomo I, Madrid, Aguilar, 2003, p. 564. El Goetz goethiano, un caballero libre «que sólo depende de Dios, su Emperador y él mismo», se convierte en caudillo de los campesinos a cambio de moderación en sus filas [«ipor qué os habéis echado al campo? ¿Por recobrar vuestros derechos y libertades? ¿Cuál es el motivo de vuestra rabia y la perdición del país? Si estáis dispuestos a absteneros de toda mala acción y portaros como personas honradas, que saben lo que quieren, dispuesto estoy yo también a ayudaros en vuestras reivindicaciones. Por ocho días seré vuestro capitán.» Ibid., Acto V, Escena II]. El acuerdo no le dura a Goetz ni una escena: «¡Incendiarios! ¡De ahora más que no cuenten conmigo! ¡Que se busquen un gitano que los acaudille, que yo ya terminé», en supra, p. 606. El Goetz de Goethe es un reformista... al servicio de la Restauración (de esa inexistente edad de oro medieval en que ni los nobles tenían que cambiar a sus pares por cortesanos para poder mantener con ellos una política de buena vecindad, ni a los cortesanos se les denegaba el "privilegio» de sentarse a la mesa redonda del landgrave). Es interesante comparar la relación que el Goetz de la ficción mantiene con el radicalismo reformista y la relación que el propio Goethe mantuvo con la Reforma, a la que saludó de este modo: «Volvemos a tener la valentía de estar con pie firme en la tierra de Dios y de sentirnos orgullosos de nuestra naturaleza humana, divinamente dotada»; en la confianza, ejemplar para todo cristianismo liberal, de que «Poco a poco, de un cristianismo de la Palabra y la Fe, todos llegaremos a un cristianismo de la reflexión y la acción». Citado en Löwith, Karl, De Hegel a Nietzsche. La quiebra revolucionaria del pensamiento en el siglo XIX, Buenos Aires, Katz, 2008, pp. 43-44.

5 Lutero, Obras [ed. Teófanes Egido], Salamanca, Sígueme, 1977, pp. 268s.

6 Walzer, Michael, La revolución de los santos. Estudio sobre los origenes de la política radical, Buenos Aires/Madrid, Katz Editores, 2008. (En adelante: Walzer, N. ${ }^{\circ}$ pag.)

7 Imposible dejar de acordarse del Leviathan de Hobbes (1651). Lo que vemos en Hobbes es una ten- 
dencia bastante consolidada en la Europa del siglo XVII de aplicarse en metáforas organicistas para perseverar en la teoría política acerca de la formación y legitimidad del Estado. El caso de Hobbes es particularmente interesante porque pocas veces como al leer a este teórico del pacto social podemos hacernos cargo de cuáles fueron las bases de cierta ideología inmunitaria que marcó el devenir de Europa: no es que seamos un cuerpo que debe ser protegido, sino que podremos protegernos sólo en caso de que nos constituyamos como un cuerpo. Con lo que la alegoría de raíz más orgánica imaginable asume ya en el siglo XVII que su mundo de uso va a ser el de la artificialidad: cuerpo inventado, cuerpo artefacto.

Consecuentemente, el paradigma inmunitario más clásico impregna de arriba abajo la definición hobbesiana de Ley Natural (lex naturalis), inmutable y eterna: una regla que prohíbe al hombre tanto aceptar aquello que destruye su vida, o que le arrebata los medios de preservar la misma, cuanto omitir aquello otro con que puede mejorarla, sabiendo siempre que la igualdad es la comadrona de la inseguridad mientras que la libertad y el miedo son radicalmente compatibles. ¿Y cuáles son los principios conforme a los cuales se construye ese Cuerpo total de obediencia que llamamos civitas - el poder constituido como herramienta de seguridad una vez que se comprueba que las leyes de la naturaleza, por muy eternas e inmutables que sean, no se imponen solas ni son autosuficientes? Se trata de dos principios complementarios: uno, teratológico, dice que ese Cuerpo-República ha de ser monstruoso en su unidad, prodigioso en su conformación, no natural; otro, teatral, dice que ese Cuerpo-república es siempre prosopon, esto es, persona, enmascarado, actor que representa de forma vicaria, autorizada o delegada las palabras y las acciones cuya propiedad detentan los representados (los autores). Inútil es reprocharle algún exceso a la persona que es Leviatán, pues su anatomía terroríficamente excesiva es precisamente lo que garantiza la seguridad común gracias al poder disuasorio del miedo, absurdo recriminarle alguna acción pues su carácter artificial lo defiende ante cualquier ataque devolviendo como una pelota al querellante sus reproches, pues él mismo, y no Leviatán, es autor y propietario de los actos del coloso. A ese cuerpo colosal que es Leviatán el teatro, la actoría y no la autoría, le salva de la responsabilidad del mal.

Tanto por lo que tiene de colosal cuanto por lo que tiene de actor, la nota fundamental de ese cuerpo es su ausencia de naturalidad. No hay naturalidad alguna allí donde precisamente es necesario invertir en alegorías naturalistas, preferiblemente botánicas, para entender el papel del Estado moderno: el pueblo es la inflorescencia del monstruo y su organización es similar a la de una especie de Helianthus que vira conforme a la dirección del sol. El Leviathan hobbesiano es el Río Grande de la célebre hipótesis crística de Ernst Kantorowicz [vid., Kantorowicz, E., The King's two bodies,
Princeton, Princeton University Press, 1957]: el lugar en que se desmantela la mística en torno a los dos cuerpos del rey, el corruptible y el sobrenatural, el administrativo y el eterno, la frontera sobre la cual toda la teología política medieval comienza a resolverse por medio de un contrato que responde racionalmente a la angustia producida por la comprensión de que el trono es un lugar vacío de Dios. En Hobbes, los derechos del poder y el deber son derivados de la naturaleza empírica de los hombres susceptible de definición razonada por acuerdo universal.

8 Shakespeare, W., La vida del rey Enrique $V$ [Acto IV, escena primera], en Obras Completas. Tragedias, Madrid, Aguilar, 2003, pp. 719s.

9 Vid., Walzer, pp. 28ss.

${ }_{10}$ Chartier, Roger, Espacio público, crítica y desacralización en el siglo XVIII, Barcelona, Gedisa, 1995, pp. 216ss.

11 Chartier, R., opus citat., p. 219.

12 Walzer, p. 145.

13 Milton, John, El paraíso perdido (Libro II, 365-385), Madrid, Cátedra, 1998, pp. 118s.

14 Walzer, p. 33.

15 Vid., Walzer, pp. 285 y ss. [Capítulo «La política y la guerra»].

16 Claraval, Bernardo de, Elogio de la nueva milicia templaria, Madrid, Siruela, 2005, p. 45s.

17 Citado en Hill, Christopher, El mundo trastornado. El ideario popular extremista en la Revolución inglesa del siglo XVII, Madrid, Siglo XXI, 1983, p. 381 .

18 Hill, Christopher, El mundo trastornado. El ideario popular extremista en la Revolución inglesa del siglo XVII, Madrid, Siglo XXI, 1983, pp. 355ss. Una precisión de lexicografía política: convencionalmente se da por hecho que la palabra «Revolución» no adquiere su significado político antes de 1688. Y que previamente era un término astronómico limitado al curso de los cielos o cualquier otro movimiento circular completo, en sí mismo neutral y carente de la connotación del «progreso». Christopher Hill rastrea un uso político moderno de la palabra antes de esa fecha en Hill, C., A Nation of Change and Novelty. Radical politics, Religion and Literature in seventeenth-century England, London and New York, Routledge, 1990 (cap. 5 The word «Revolution»), pp. 82ss. También Lanceros, P., Politica mente, Barcelona, Anthropos, 2005, p. 44, nota 5 .

19 Walzer, p. 319

20 Vid., Luhmann, Niklas, La religión de la sociedad, Madrid, Trotta, 2007, pp. 241ss. (Me remito al excelente capítulo 8 titulado precisamente «Secularización».)

21 Luhmann, N., opus citat., p. 246.

22 Vid., Lübbe, Hermann, Säkularisierung. Geschichte eines ideenpolitischen Begriffs, Freiburg, Karl Alber, 1975 (primera edición 1965). 
23 Evidentemente, me refiero a la obra de Marramao, G., Cielo y Tierra. Genealogía de la secularización, Barcelona, Paidós, 1998.

24 Sin embargo, considero muy valiosa la posición de Giacomo Marramao cuando avisa de los reduccionismos que amenazan al establecer una arqueología de la legitimidad de la modernidad en exceso decantada hacia el polo de la Autoafirmación (Selbstbehauptung): «habría que examinar si $-\mathrm{y}$ en qué medida - la propia dimensión típicamente occidental de la «autodecisión» y de la «consciencia de Sí» dependen - no ya también sino señaladamenteen el mundo moderno de modelos conceptuales, códigos simbólicos y cuadros metafóricos de heterointegración de los sujetos. O, más puntualmente, si y qué medida la clave de este mecanismo de heterodeterminación no está más bien en los pilares categoriales portadores de la modernidad: «progreso», «revolución» y (concepto moderno par excellence) «liberación». $\mathrm{O}$, más precisamente aún, en el rasgo que los pone en relación y los fundamenta: la forma de la temporalidad propia del Occidente moderno.» Vid., Marramao, G., Poder y secularización, Barcelona, Península, 1989, p. 29.

25 Vid., la versión en español: Löwith, Karl, Historia del mundo y salvación, Buenos Aires, Katz, 2007.

26 Vid., Löwith, Karl, El hombre en el centro de la historia, Barcelona, Herder, 1998, pp. 138s; 158s.

27 Wetz, Franz Josef, Hans Blumenberg. La modernidad y sus metáforas, València, Alfons El Magnànim, 1996, p. 38ss.

28 Blumenberg, Hans, Die Legitimität der Neuzeit, Frankfurt am Main, Suhrkamp, 1999.

29 Vid., en adelante Wetz, F. J., supra, p. 43s.

30 Vid., Löwith, Karl, Historia del mundo y salvación. Los presupuestos teológicos de la filosofía de la historia, supra.

31 Un tratamiento hermenéutico de la tesis según la cual «Occidente es cristianismo secularizado» queda bien ilustrado por la obra reciente de Vattimo, Gianni, Después de la cristiandad. Por un cristianismo no religioso, Barcelona, Paidós, 2003, pp. 89ss.

32 Vid., Gauchet, Marcel, El desencantamiento del mundo. Una historia política de la religión, Madrid, Trotta, 2005, pp. 49ss.

33 Ibidem, p. 51.

34 Gauchet, M., opus cit., p. 53.

35 Esposito, Roberto, Categorías de lo impolítico, Buenos Aires, Katz, 2006, p. 14.

36 Zarka, Yves Charles, Figuras del poder. Estudios de filosofia politica de Maquiavelo a Foucault, Madrid, Biblioteca Nueva, 2004, p. 165. Sobre este punto, vid. el excelente ensayo «Hacia la guerra perpetua. La política del miedo y el miedo a la política», en Lanceros, P., Política mente. De la revolución a la globalización, Barcelona, Anthropos, 2005 , pp. 51 ss.

37 Walzer, p. 276.
38 Me estoy refiriendo, claro está, a la doctrina desarrollada en 1996 por Harlan Ullman para la administración norteamericana y el Instituto de Estudios Estratégicos Nacionales de los EEUU, en su conocida instrucción militar «Shock and Awe: Achieving Rapid Dominance». Pasando por alto el reporte de analogías que Ullman establece entre su doctrina y la experiencia de ¡Sun-Tzu, las Legiones romanas, Hitler o la Bomba Atómica de Hiroshima!, entre otras, incluyo este extracto como anexo a mi relato

«El fundamento de la Dominación Rápida radica en la habilidad para afectar la voluntad, percepción y comprensión del adversario a través de la imposición de suficiente Conmoción y Pavor en orden a lograr los objetivos políticos, estratégicos y operativos del conflicto o crisis que conduzca a usar la fuerza. $[\ldots]$

En la Dominación Rápida, el impulso de menoscabar la voluntad, el entendimiento y la percepción del adversario, a través del logro de Conmoción y pavor, es multifacético. Para identificar y presentar estas facetas, precisamos examinar primero diferentes aspectos y mecanismos por los cuales Conmoción y pavor afectan al adversario. Uno se acuerda de las viejas fotografías y películas o programas televisivos, las comatosas y vidriadas expresiones de los supervivientes de los grandes bombardeos durante la I Guerra Mundial y los horrores y la muerte de los ayudantes en la guerra de trincheras. Estas imágenes y expresiones de shock trascienden la raza, la cultura y la historia. Por eso, la cobertura televisiva de la Tormenta del Desierto retrató vívidamente cómo los soldados iraquíes registraban estos efectos de un campo de batalla estilo conmoción y pavor.

En nuestra excursión, perseguimos determinar cuánto y cómo pueden devenir la Conmoción y el Pavor en factores suficientemente intimidatorios y persuasivos para forzar, o de otro modo convencer, al adversario para que acepte nuestra voluntad en el sentido clausewitzeano, de forma que los propósitos estratégicos y los objetivos militares de la campaña conquisten un final político. Así, Conmoción y Pavor están vinculados a cuatro características nucleares que definen la Dominación Rápida: conocimiento, rapidez, brillantez y control. $[\ldots]$ ».

39 Sloterdijk, Peter, En el mismo barco. Ensayo sobre hiperpolítica, Madrid, Siruela, 2000.

40 En la monumental reseña-prólogo a la obra de Genet: Sartre, J. P., «San Genet, comediante y mártir», Buenos Aires, Losada, 2003 [el original, en Gallimard, de 1952].

41 Koselleck, Reinhart, Critica y crisis. Un estudio sobre la patogénesis del mundo burgués, Madrid, Trotta, 2007, pp. 130s.

$42 \mathrm{Y}$ añade «El pagaré fue saldado por vez primera en la Revolución francesa». Koselleck, R., op. cit., p. 162. 
43 En un marco teórico muy diferente, vid. este problema en Jameson, F., Las semillas del tiempo, Madrid, Trotta, 2000, p. 70.

44 Es interesante poner esto en relación con la genealogía del Mundo Moderno realizada por Arendt como un disfrazado entrejuego de sustituciones entre la vita contemplativa y la vita activa (en cuyo seno surge la descompensadora figura del homo faber), en Arendt, Hannah, La condición humana, Barcelona, Paidós, 2005, p. 321.
45 Zarka, Y. Ch., Figuras del poder, supra, pag. 22. A continuación me baso en las pp. 133-139, sobre todo.

46 Foucault, Michel, La verdad y las formas jurídicas, Barcelona, Gedisa, 2001, p. 59.

47 Jünger, Ernst, Radiaciones. Diarios de la Segunda Guerra Mundial, Memorias, vol. 1, Barcelona, Tusquets, 1995, p. 244.

48 Jünger, Ernst, Radiaciones, Diarios de la Segunda Guerra Mundial. Memorias, vol. 2, Barcelona, Tusquets, 1992, pp. 415-416. 